\title{
The Impact of Physical Facilities on Quality of Primary Education in Khyber Pakhtunkhwa as Perceived by Teachers
}

\author{
Sayyed Farooq Shah, Irfan Ullah khan, Dilfaraz khan, Muhammad Faheem khan \\ Sayyed Farooq Shah (corresponding Author) \\ Institute of Education \& Research \\ University of Science \& Technology, Bannu, Pakistan \\ Institute of Education \& Research University of Science \& Technology, Bannu
}

\begin{abstract}
Education plays an illuminative role in the development of a country. It is widely acknowledged that quality education is the single most important instrument in enhancing human capabilities and achieving the desired goals. The major purpose of the study was to check out the quality of Primary education in Khyber Pakhtunkhwa. All the head teachers and teachers of the Primary schools of Southern Districts of Khyber Pakhtunkhwa were the population of the study. The sample of the study was consisted of 100 head teachers (50 male and 50 female) and 300 teachers (one hundred \& fifty male and one hundred \& fifty female). The study was survey type in nature. The researcher personally developed the questionnaire to collect the data. Collected data was tabulated, analyzed, and interpreted in the light of the objectives of the study. Statistical tools like mean and standard deviation were used to analyze the data. In the light of conclusions it is recommended that physical infrastructure issue necessarily should be taken as serious and major problem because it directly affect the learners as well as teacher performances. By supplying enough number of chairs, A.v aids, fans, lighting system, bath rooms, drinking water, computer facilities, libraries, books and arranging access to basic health facilities in the shape of dispensaries quality education goal can acquired.
\end{abstract}

Keywords: Quality Education, Primary level, Teaching Kits, Staffrooms, Physical Facilities.

\section{Background}

"Primary education holds a central position in the whole educational system. At this stage the largest number of man -power is available. The educationist considers this stage as a backbone or foundation stone of the whole educational system, while sociologist considers it as an effective weapon of social reforms. It can be said that Primary education is closely related with informatory and initiative stage of the society" (Mirza, 2003) $[1]$

"Primary education is considered to be much urgent and essential element for the advancement of the countries all over the world. It is the key sector / phase of the entire education system. On one side it provides a literate workforce for the country and on the other side it works like a feeder for the next coming stages of education which directly or indirectly depends upon the quality of primary education which is the initial stage. Due to which skilled, professional and trained work force will produced which will work actively in every walk of life especially in political, social or economic fields" (Brown, 1998p) ${ }^{[2]}$

Quality of Primary education has its own importance and value for all of us. If we give Primary education a prominent place and status then we can expect from it that it will definitely add to our progress and prosperity directly or indirectly. In simple words quality of Primary education plays the role of bridge to all next coming stages of education. Therefore the progress and development of a nation depends directly on the quality of primary education. There is no second opinion, but only quality education can prepare students who can face the challenges of global market. School education is criticized over many forums that it has no quality and producing students without any knowledge and understanding of basic concepts.

Quality of education for all has emerged as one of the most desirable goals throughout the world. One of the six goals, outlined by the World Education-Dakar- Framework for Action (2000), is related to the improvement of "all aspects of quality education" in order to achieve the identified learning outcomes (UNESCO, 2000) ${ }^{[3]}$

As various factors including curriculum, delivery of content, learning environment, supervision, and administration of academic facilities contribute to the quality of education, the central importance of the teacher cannot be denied. The competence and enthusiasm of teachers determine the heights to which an educational system can rise (Iqbal, 1996) ${ }^{[4]}$. Ferguson, as cited in paliakoff and Schwartzbeck (2001) ${ }^{[5]}$, observes that quality of teachers is the most critical aspect of schooling and that it has a direct impact on student learning. 


\section{Determinants Of Education Quality}

It is difficult to define quality of education precisely mainly because of complex nature of teachinglearning process and large number of stakeholders involved in schooling,(Mirza, 2003). Various authors/ researchers have identified different determinants of education quality. Cheng and Cheung (1997) ${ }^{[6]}$ define quality of education as a set of elements containing input, process and output of education system. Based on engineering model of education, Adams' (1993) ${ }^{[7]}$ framework of quality consists of institution' reputation, resources/ input, process, content, outputs/ outcomes, and value added. According to Santos (2007) ${ }^{[8]}$, a traditional school quality model is characterized by test scores and various inputs including student family background, school characteristics, teacher characteristics and student's innate ability. The indicators of education quality identified by Thaung (2008) ${ }^{[9]}$ include learners, teachers, content, teaching-learning processes, learning environments, and outcomes. As a matter of fact, the value of Thaung's, (2008) model is yet to be discussed and analyzed in the academic literature. Another significant model of quality of education has been given by UNICEF (2000) ${ }^{[10]}$ which comprises five dimensions i.e. quality learners, quality learning environments, quality content, quality processes, and quality outcomes. Memon (2003) ${ }^{[11]}$ argues that this framework appears to be more viable and relevant if specific criteria are outlined to assess the quality of education.

\section{UNICEF Framework for the Quality of Education

Elements Quality Indicators

1. Quality of learners Students' good health and nutrition, early childhood psychosocial development experiences, regular attendance, and family support for learning.

2. Quality of learning environments Physical elements (e.g. school facilities, class size etc.), psychosocial elements (e.g. safe environment, teachers' behavior, discipline policies, non-violence etc.), and service delivery (e.g. health services).

3. Quality of contents Student-centered and standard based curriculum, uniqueness of local and national content, and focus on literacy, numeracy, and life skills.

4. Quality of processes Indicators relating to teachers and teaching (e.g. teachers' competence, support for student-centered learning, participation based teaching methods, teachers' working conditions etc.), and supervision and support (e.g. administrative leadership, effective use of technology, diversity of processes and facilities etc.)

5. Quality of outcomes Students' achievement in literacy and numeracy, life skills, health outcomes, outcomes sought by parents, community participation, and learners' confidence, UNICEF (2000).

Quality of education assumes that existence of adequate physical infrastructure is much urgently needed. It also assumes that such quality infrastructure should not be compromised by any means for the institution. The quality of infrastructure of the internal \& external environment is closely related to the quality of education. Investments in the development of the physical facilities of the institution go a long way in improving quality education. Basic facilities like school building, electricity, laboratories drinking water are the basic requirements for education. Without these basic facilities quality education is very difficult and almost impossible. For quality education, these facilities are compulsory and mandatory. Inadequate facilities are one of major challenge and hurdle in the way of quality education. Well organized and fully equipped institutions smoothen the way of quality education UNESCO, (1998) ${ }^{12]}$.

Quality of education and research assume that existence of adequate physical infrastructure needs. It also assumes however that such infrastructure is managed \& maintained in the best possible in the institution, interest \& not mainly for the convenience of the managers. The quality of infrastructure of the internal \& external environment is closely related to quality of education. Investments in the development of the physical facilities of the institution go a long way in improving quality education. Basic facilities like school building, electricity, laboratories drinking water are necessities for education. Without these facilities education is very difficult. For quality education, these facilities are compulsory. Inadequate facilities are one of the challenges in the way of quality education

\section{Material And Methods}

The major purpose of the study was to investigate the quality of education at Primary level in Khyber Pakhtunkhwa. The study was descriptive / survey type in nature. All the head teachers and teachers of Government Primary Schools of the five southern districts of Khyber Pakhtunkhwa constituted as the population of the study. The sample of the study consisted of 100 heads teachers, 300 teachers from the southern districts of Khyber Pakhtunkhwa who were randomly selected. For collection of data, researcher personally developed two questionnaires. The questionnaires were validated through pilot testing before administering to the respondents. The data was collected through administering the questionnaires through pilot testing. For this purpose the researcher personally visited the sample institutions and respondents. Data collected through the above 
mentioned research instruments was tabulated, analyzed and interpreted using inferential statistics like mean and standard deviation in the light of the objectives of the study.

\section{Data Analysis}

Data collected through the above mentioned research instruments was tabulated, analyzed and interpreted through mean and standard deviation in the light of the objectives of the study. The most suitable statistical tools like mean, standard deviation, standard error of mean and estimated population mean were applied for getting the results.

Table: Aspect of physical facilities available at Primary Level

\begin{tabular}{|c|c|c|c|c|c|c|c|c|c|}
\hline Statement & $S E_{\bar{X}}$ & $\mu$ & $\mathbf{S A}$ & $\mathbf{A}$ & UD & DA & SDA & M & SD \\
\hline $\begin{array}{l}\text { Teaching kits are } \\
\text { available in the school. }\end{array}$ & .033 & $1.33-1.46$ & 272 & 105 & 16 & 5 & 2 & 1.40 & 0.67 \\
\hline $\begin{array}{l}\text { Water facility is available } \\
\text { in the school. }\end{array}$ & .027 & $1.19-1.30$ & 318 & 69 & 8 & 5 & 23 & 1.25 & 0.55 \\
\hline $\begin{array}{l}\text { School is protected by } \\
\text { enough boundary walls. }\end{array}$ & .031 & $1.24-1.37$ & 302 & 81 & 9 & 7 & 1 & 1.31 & 0.62 \\
\hline $\begin{array}{l}\text { Toilet facility is available } \\
\text { for students }\end{array}$ & .020 & $1.10-1.18$ & 348 & 49 & 35 & 13 & 6 & 1.14 & 0.41 \\
\hline $\begin{array}{l}\text { Furniture is available in } \\
\text { the class for students. }\end{array}$ & .058 & $1.70-1.92$ & 245 & 52 & 38 & 62 & 3 & 1.81 & 1.16 \\
\hline $\begin{array}{l}\text { Proper school building is } \\
\text { available }\end{array}$ & .029 & $1.23-1.34$ & 307 & 67 & 12 & 11 & 5 & 1.28 & 0.58 \\
\hline $\begin{array}{l}\text { Enough class rooms are } \\
\text { available. }\end{array}$ & .048 & $1.51-1.71$ & 256 & 79 & 28 & 34 & 2 & 1.61 & 0.97 \\
\hline $\begin{array}{l}\text { Class rooms are well } \\
\text { furnished and airy. }\end{array}$ & .035 & $1.32-1.45$ & 283 & 90 & 17 & 8 & 2 & 1.39 & 0.71 \\
\hline $\begin{array}{l}\text { Play ground is available } \\
\text { for students. }\end{array}$ & .056 & $1.94-2.16$ & 162 & 116 & 74 & 33 & 15 & 2.05 & 1.12 \\
\hline $\begin{array}{l}\text { Separate staff room is } \\
\text { available for teachers in } \\
\text { the school. }\end{array}$ & .076 & $2.70-3.00$ & 128 & 42 & 67 & 85 & 78 & 2.85 & 1.53 \\
\hline
\end{tabular}

The table reveals that A.V aid like teaching kits are available which is the most necessary thing in teaching as the mean of the responding falls in the agree row, also the basic facilities like water ,boundary walls toilets ,proper school building were available in their respective institutions as the means clearly indicates the facts. Most of the respondents unanimously declared that separate staff rooms for the teachers were not present as the ranged in the undecided row which can be observed from the mean position too.

\section{Results}

The following results were drawn from analysis of the data

1. The Mean rating score and Standard deviation of respondents on the statement that teaching kits are available in the school were 1.40 and 0.67 respectively hence, majority of the respondents looked strongly agree to this statement.

2. The Mean rating score and Standard deviation of respondents on the statement that water facilities are available in the school were 1.25 and 0.55 respectively hence, majority of the respondents looked strongly agree to this statement.

3. The Mean rating score and Standard deviation of respondents on the statement that school is protected by enough boundary walls were 1.31 and 0.62 respectively hence, majority of the respondents looked strongly agree to this statement.

4. The Mean rating score and Standard deviation of respondents on the statement that toilet facilities are available for students were 1.14 and 0.41 respectively hence, majority of the respondents looked strongly agree to this statement.

5. The Mean rating score and Standard deviation of respondents on the statement that furniture is available in the class for students were 1.18 and 1.16 respectively hence, majority of the respondents looked strongly agree to this statement.

6. The Mean rating score and Standard deviation of respondents on the statement that proper school building is available were 1.28 and 0.58 respectively hence, majority of the respondents looked strongly agree to this statement. 
7. The Mean rating score and Standard deviation of respondents on the statement that enough class rooms are available were 1.61 and 0.97 respectively hence, majority of the respondents looked strongly agree to this statement.

8. The Mean rating score and Standard deviation of respondents on the statement that class rooms are well furnished and airy were 1.39 and 0.71 respectively hence, majority of the respondents looked strongly agree to this statement.

9. The Mean rating score and Standard deviation of respondents on the statement that play grounds are available for students were 2.05 and 1.17 respectively hence, majority of the respondents looked agree to this statement.

10. The Mean rating score and Standard deviation of respondents on the statement that separate staff room is available for teachers in the school were 2.85 and 1.53 respectively hence, majority of the respondents looked undecided to this statement.

\section{Discussion}

Primary education holds a key or central position in the whole educational system. Here at this very stage the largest number of man -power is available. The educationist considers this stage as a backbone or foundation stone of the whole educational system, while sociologist considers it as a useful mace of communal reforms. It can be believed that primary education is intimately associated with informatory and initiative stage of the society Mirza, (2003).

Primary education is measured much urgent and obligatory for the emergent countries of the world. It is the key sector or phase of the entire education system. It provides a literate workforce for the country and in additional it acts as a feeder for the next coming secondary education. The quality of secondary education which is likely to generate high quality of skilled professionals in diverse fields of social, economic \& political life of the country depends upon the quality of primary education. This stage needs to be prepared in such a way that should prepare little lads for the chase of secondary education, as well as to make them able to amend with their practical lives evocatively and efficiently Brown, (1998).

The lonely most important thing that impacts the prospect of the country and its youthful people is right of entry to quality education. Quality of primary education directly influences the quality of secondary and higher secondary education. The present study showed that libraries were not present in nearly all schools of province with no books or allied material facility. The reason may be lack of financial resources, if where they were present the books and allied material is outdated. Evaluation and assessment system although regularly organized but the system is not as much transparent as supposed to be, it may due to sincere staff, impartial duty staff, reliable check and balance examining body and political interference.

To improve the quality of education physical infrastructure issue necessarily be taken as serious and major problem because it directly affect the learners as well as teacher. By supplying enough number of chairs, A.v aids, fans, lighting system, bath rooms, drinking water, computer facilities, libraries, books and arranging access to basic health facilities in the shape of dispensaries quality education goal can acquired.

\section{Conclusions}

On the basis of the findings and results of the study, the following conclusions were made:

1. Teaching kits were provided by the Govt. to majority of the schools, water, toilet facilities were present and proper protection was given to the institution by boundary walls as revealed by majority respondent's opinions, but separate staff room were not present for the teachers for mini break recreations..

2. Majority of the respondents opined that enough play grounds facilities for co-curricular activities were present.

3. Majority of the respondents viewed that buildings, rooms, trained teaching staff and basic physical facilities were present sufficiently but furniture, office staff, staff rooms; library and books in library were present to some extent, although majority of the respondents unanimously opined that computer and dispensary facilities were not present in nearly all the primary schools.

\section{Recommendations}

In the light of findings and conclusions the following recommendations were made by the researcher.

1. Findings revealed that Computer facility is not present in majority of our schools. It is recommended that this issue may be tackled on emergency priority basis, and special funds may be allocated to provide at least a single computer set to each and every school so that every child can acquire necessary computer skills. In this regard local community and other donating agencies can be mobilized for funding purposes.

2. The result of the study revealed that basic health facilities were not available in most of our schools so this is another alarming issue which needs to be resolved as a special case. Although, we have lack of financial resources and cannot afford extra burden on the exchequer, yet this can be acquired with the help of 
prosperous community members' participations so that first aid can be supplied if some unpleasant happens seldom.

3. Findings showed that separate staff rooms were not present for the teachers. In this connection it is recommended that in each school a staff room may be constructed, so that in the spire times the teachers take some rest $\&$ make preparation for the next periods afterwards.

\section{ACKNOWLEGDMENTS}

First of all, I am thankful to Almighty "Allah", the most merciful and beneficent; who gave strength, ability and opportunity to seek knowledge, and His blessings enabled me to achieve my goals. I am grateful to Holy Prophet Hazrat Muhammad (Peace Be Upon Him) who is forever a true torch of guidance for whole humanity and who showed right direction to humanity and enabled us to recognize our creator. Researcher would like to take this opportunity to express my appreciation to the people who have helped me to pursue this degree and write this dissertation.

Researcher owes a massive debt of gratefulness to my supervisor Dr. Saqib Shahzad Assistant Professor. For his valuable suggestions, back-up, and confidence for directing $\mathbf{m y ~} \mathbf{M}$. Phil degree and providing assistance, guidance and inspiration for every step of the research and writing of my thesis. Researcher would also like to thank Dr. Safdar Rehman Ghazi Director Institution of Education and Research University of Science and Technology Bannu, Dr. Muhammad Ayaz Assistant Professor and Dr. Rehmat Ullah Shah Assistant Professor IER for his kindness, help and full co-operation. Researcher would like to thank all my close friends, teachers and colleagues who helped me during my thesis and assist me during compilation of my research data.

In the end, researcher take this opportunity to express his deep gratefulness to his beloved father (Late) Sardar Khan to my sweet sisters, my brothers M. Israr Khan, M. Ishaq Khan, Hafiz Amir Ullah, for their support, motivation for higher thoughts, love, care, moral and financial support and limitless prays for my splendid success about my pursuits right through my life.

S. F. Shah

\section{References}

[1] Mirza, M. (2003). Quality of primary education in Pakistan a research study, 2003

[2] Brown, (1998). The Madrassahs resource centers and their community-based preschool Programme.

[3] UNESCO, (2000). World education forum: Dakar framework for action 2000. Paris: UNESCO

[4] Iqbal, Z. (1996). Teacher training: The Islamic perceptive. Islamabad: Institute of Policy Studies

[5] Schwartzbeck T.D. (Eds). (2001). Eye of the storm: Promising practices for improving instruction. Washington D.C.: CBE

[6] Cheng, Y. \& Cheung, W. (1997). Multi-model of education quality and multi levels of self anagement in schools. Educational Management and Administration, 25 (4), 26-37.

[7] Adams D. (1993). Defining education quality. In improving educational quality project Publication \# 1. Biennial report. Arlington, V.: Institute for International Research.

[8] Santos, M.E. (2007). Quality education in Argentina: Determinants and distribution using PISA test scores. Retrieved June 8, 2010 from siteresources.worldbank.org/EDUCATION/.../Session II Maria Emma Santos4.pdf

[9] Thaung, N.N. (2008). Quality indicator, A paper presented in the Capacity Building Workshop on Monitoring and Evaluating Progress in Education in the Pacific in Nadi, FIJI on 27-31 October 2008.

[10] UNICEF, (2000). Defining quality in education. A paper presented at the International Working Group on Education meeting, Florence Italy, June 2000. (Principal researcher: Jeanette Colby).

[11] Memon, M. (2003). The quality of education in Pakistan: A national policies perspective. A paper presented in the conference on The Research and Policy Dialogue on Achieving Quality in Education held in Lahore on March 4-5, 2003.

[12] UNESCO, (1998). Learning achievement in primary schools of Pakistan. A quest for quality education Islamabad Pakistan 